\title{
Uptake of Precursor and Synthesis of Transmitter in a Histaminergic Photoreceptor
}

\author{
Jennifer R. Morgan, ${ }^{1}$ Kelley A. Gebhardt,, ${ }^{2}$ and Ann E. Stuart ${ }^{2}$ \\ ${ }^{1}$ Department of Neurobiology, Duke University Medical Center, Durham, North Carolina 27710, and 2Department of Cell \\ and Molecular Physiology, University of North Carolina at Chapel Hill, Chapel Hill, North Carolina, 27599-7545
}

As a first step in understanding how the supply of the neurotransmitter histamine is maintained in a photoreceptor, we followed the uptake and metabolism of the immediate precursor of histamine, histidine. $\left[{ }^{3} \mathrm{H}\right] \mathrm{Histidine}$ taken up into photoreceptors and glia was detected using autoradiography, and synthesis of $\left[{ }^{3} \mathrm{H}\right]$ histamine from $\left[{ }^{3} \mathrm{H}\right]$ histidine was assayed with thinlayer chromatography. Photoreceptors from barnacles were pulsed (15 min) with [ $\left.{ }^{3} \mathrm{H}\right]$ histidine $(0.2-200 \mu \mathrm{M})$, then maintained in normal saline for up to $24 \mathrm{hr}$. Autoradiography showed that photoreceptor somata, axons, and presynaptic arbors were labeled, but only weakly, like (nonhistaminergic) ganglion cells. Label instead was concentrated over surrounding glia. Stimulating preparations with light did not increase photoreceptor labeling. Grain counts from photoreceptor axons showed uptake of $\left[{ }^{3} \mathrm{H}\right]$ histidine into these neurons by a $\mathrm{Na}^{+}$-dependent mechanism with a $K_{\mathrm{m}}$ of $\sim 50 \mu \mathrm{M}$. Over $24 \mathrm{hr}$ only $1 \%$ of the $\left[{ }^{3} \mathrm{H}\right]$ histidine taken up by preparations was converted to $\left[{ }^{3} \mathrm{H}\right]$ histamine either in the dark or in the light. Injections of $\left[{ }^{3} \mathrm{H}\right]$ histidine directly into photoreceptors established that synthesis takes place within the photoreceptors and confirmed that stimulation with light did not measurably affect the rate of conversion of $\left[{ }^{3} \mathrm{H}\right]$ histidine to $\left[{ }^{3} \mathrm{H}\right]$ histamine. These results suggest that de novo synthesis of transmitter is unlikely to be as important as its reuptake in maintaining neurotransmitter supply in these photoreceptor terminals. In support of this conclusion, photoreceptors accumulated more label when transmitter release was stimulated with high $\mathrm{K}^{+}$and histamine uptake was antagonized with chlorpromazine.

Key words: histamine; neurotransmitter synthesis; histidine uptake; photoreceptor; arthropod; barnacle
Both vertebrate and invertebrate photoreceptors release transmitter continuously in the light and in the dark. How the supply of neurotransmitter is maintained in the face of such constant release is not well understood for either cell type. Neurotransmitter stores in general are replenished by both synthesis and reuptake. To detail how the supply is maintained one would ultimately wish to know the relative contributions of uptake and synthesis in maintaining the neurotransmitter pool and the sites and methods of regulation of these pathways.

Many arthropod photoreceptors use histamine as their neurotransmitter (Hardie, 1987; Nassel et al., 1988; Pirvola et al., 1988; Simmons and Hardie, 1988; Battelle et al., 1991; Sarthy, 1991; Stuart and Callaway, 1991; Burg et al., 1993; Stuart et al., 1996). Because this molecule is uncommon in nervous systems and does not participate in intermediary metabolism, its synthesis and uptake may be tracked relatively easily. Histamine is synthesized from histidine by a one-step decarboxylation process via the enzyme histidine decarboxylase. Existence of this pathway has been demonstrated for a variety of simple and compound eyes in arthropods (Manduca, Maxwell et al., 1978; Schistocerca, Elias and Evans, 1983; Drosophila, Sarthy, 1991; Limulus, Battelle et al., 1991) including barnacle photoreceptors (Callaway and Stuart, 1989). Specific, high-affinity uptake of $\left[{ }^{3} \mathrm{H}\right]$ histamine has also been shown for barnacle photoreceptors (Stuart and Callaway, 1991; Stuart et al., 1996).

\footnotetext{
Received Sept. 30, 1998; revised Nov. 24, 1998; accepted Nov. 25, 1998.

This work was supported by United States Public Health Service Grant EY03347 to A.E.S. We thank Kathy Chung for excellent technical assistance, Kevin Martin for help with the intracellular injections, and Barbara Battelle for constructive comments on this manuscript.

Correspondence should be addressed to Ann E. Stuart at the above address. Copyright (C) 1999 Society for Neuroscience $0270-6474 / 99 / 191217-09 \$ 05.00 / 0$
}

It has generally been assumed that the histamine synthesis observed in arthropod eyes takes place in the photoreceptor neurons themselves rather than in surrounding glia. These experiments address the role of the synthetic pathway in the photoreceptors: whether $\left[{ }^{3} \mathrm{H}\right]$ histidine is taken up more avidly into photoreceptors than into nonhistaminergic cells, whether an unusually high rate of transmitter synthesis might be required to maintain the transmitter supply in these continuously releasing cells, and whether the rate of synthesis is markedly affected by stimulation of the photoreceptors with light. Our results suggest that, although de novo synthesis must maintain the histamine supply in the long run, it does not appear to do so over periods of hours: $\left[{ }^{3} \mathrm{H}\right]$ histidine is taken up only sparsely into photoreceptors, as into other neurons, compared with surrounding glia; $\left[{ }^{3} \mathrm{H}\right]$ histamine is synthesized relatively slowly, at a rate characteristic of amino acid neurotransmitters; and stimulation of the photoreceptors with light does not measurably affect $\left[{ }^{3} \mathrm{H}\right] \mathrm{histi}-$ dine uptake or $\left[{ }^{3} \mathrm{H}\right]$ histamine synthesis. These experiments suggest that the avid, activity-dependent uptake of histamine observed in these photoreceptors (Stuart et al., 1996) is primarily responsible for maintaining the transmitter supply.

The present results were reported previously in abstract form (Morgan and Stuart, 1996).

\section{MATERIALS AND METHODS}

Animals and preparations. Giant barnacles (Balanus nubilus) were obtained from Bio-Marine Enterprises (Seattle, WA) and maintained at $11^{\circ} \mathrm{C}$ in aerated, circulating artificial seawater. Preparations were dissected as described in Hudspeth and Stuart (1977) in barnacle saline containing (in mM): $461.5 \mathrm{NaCl}, 8 \mathrm{KCl}, 20 \mathrm{CaCl}_{2}, 12 \mathrm{MgCl}_{2}$, and Tris (hydroxymethyl) aminomethane $\mathrm{HCl}$ buffer, $\mathrm{pH}$ 7.6-7.8.

Preparations consisted of: the median eye (ocellus), comprising four photoreceptor somata and their surrounding glia; the median ocellar 
nerve, surrounded by capsular tissue, containing the photoreceptor axons and some tens of smaller axons each surrounded by glia (Hudspeth and Stuart, 1977); and the supraesophageal ganglion where the photoreceptors arborize and terminate.

Incubations. L-[2,5] [ $\left.{ }^{3} \mathrm{H}\right]$ histidine dihydrochloride (Amersham, Arlington Heights, IL; specific activity $40-60 \mathrm{Ci} / \mathrm{mmol}$ ) was divided into aliquots, dried down to remove the ethanol carrier, and redissolved in barnacle saline to $0.2,2,10,20,40$, or $200 \mu \mathrm{M}(20-40 \mu \mathrm{l}$; pH 7.6-7.8). Preparations were incubated in 20-30 $\mu$ l Sylgard wells. Incubations were for $15 \mathrm{~min}$ or $23 \mathrm{hr}$ at $15^{\circ} \mathrm{C}$ in flashing light of moderate intensity $(0.13$ $\mathrm{mW} / \mathrm{cm}^{2} ; 2 \mathrm{sec}$ on $/ 6 \mathrm{sec}$ off) or in the dark. Incubations in salines of altered ionic composition or containing a drug were preceded by preincubation in that saline for 15-30 min. Preparations were dark-adapted for 30 min before dark incubations.

After incubation, the $\left[{ }^{3} \mathrm{H}\right]$ histidine was washed off at $5 \mathrm{ml} / \mathrm{min}$ for $5-15$ min. Dark-incubated preparations were washed for at least $5 \mathrm{~min}$ in the dark before further processing. For pulse-chase experiments, washed preparations were either fixed immediately after the wash or returned to normal saline for 1,5 , or $24 \mathrm{hr}\left(15^{\circ} \mathrm{C}\right.$, flashing light $)$ before being fixed for autoradiography. Preparations were fixed in $2.5 \%$ glutaraldehyde (EM Sciences) in $0.2 \mathrm{M} \mathrm{Na}^{+}$cacodylate buffer, pH 7.7 (Stuart et al., 1996).

Autoradiography and grain counting. After fixation, preparations were sectioned at $2 \mu \mathrm{m}$ and processed for autoradiography (Stuart et al., 1996). Sections of ocelli, ocellar nerves, and ganglia were separately photographed with phase-contrast or dark-field optics. Photographs were printed at a final magnification of $600 \times$, and grains were counted in a square or rectangular area equivalent to $254 \mu \mathrm{m}^{2}$ of tissue. For each preparation, counts were averaged from three to eight areas for photoreceptor somata and axons and from at least two areas for the glia. Background in the section (outside the tissue) was determined from the average of 5-12 areas and subtracted from the tissue counts.

Thin-layer chromatography. Synthesized $\left[{ }^{3} \mathrm{H}\right]$ histamine was separated from $\left[{ }^{3} \mathrm{H}\right]$ histidine in pulse-chase experiments using a procedure slightly modified from Callaway and Stuart (1989). One to four preparations were pinned together in a Sylgard well and incubated in $40 \mu \mathrm{l}$ of $\left[{ }^{3} \mathrm{H}\right]$ histidine $\left(20 \mu \mathrm{M} ; 15^{\circ} \mathrm{C}\right.$; flashing light) for $15 \mathrm{~min}$. After incubation, the preparations were washed with $5 \times 250 \mu$ l of normal barnacle saline. After each wash, a $100 \mu$ l aliquot was removed from the incubation well and counted to ensure that the efflux of extracellular radioactivity had stabilized at a low level. The preparations were then further incubated in flashing light for 1,5 , or $24 \mathrm{hr}\left(15^{\circ} \mathrm{C}\right)$. In another set of experiments, preparations were incubated in $\left[{ }^{3} \mathrm{H}\right]$ histidine for $23 \mathrm{hr}$, then washed. After either protocol of incubation and wash, preparations were transferred to an Eppendorf tube, homogenized in $40 \mu \mathrm{l}$ of formic acid (1 M) acetone $(15: 85 ; \mathrm{v} / \mathrm{v})$, frozen and thawed three times, and centrifuged for 5 min. Supernatants were chromatographed on Polygram SIL G/UV sheets (Macherey-Nagel, Doren, Germany) in an HPLC-grade solvent system of 2 chloroform: 2 methanol:1 ammonium (Elias and Evans, 1983). Unlabeled standards of histamine and histidine (2 nmol), previously determined to run at the same location as $\left[{ }^{3} \mathrm{H}\right]$ histamine and $\left[{ }^{3} \mathrm{H}\right]$ histidine, were added to each lane, co-chromatographed with the supernatant samples, and visualized with sulfanilic acid. After chromatography, each lane was cut into 0.5 or $1 \mathrm{~cm}$ sections; radioactivity was eluted in $400 \mu \mathrm{l}$ of $0.1 \mathrm{~N} \mathrm{HCl}$ and measured by scintillation counting.

Intracellular injections. Preparations were prepared for intracellular recording from photoreceptors and ganglion cells as previously described (Hudspeth and Stuart, 1977). Briefly, preparations were secured to a Sylgard bottom in a two-compartment chamber and arranged so that the ganglion was superfused separately from the ocellus, the ocellar nerve passing through the barrier separating the compartments. The capsule surrounding the nerve cells was softened with Protease (Sigma, St. Louis, MO) $(3-4 \mathrm{mg} / \mathrm{ml}, 3 \mathrm{~min}$ at room temperature) to facilitate electrode impalements. The preparation was superfused with normal saline at $10-15^{\circ} \mathrm{C}$ during the experiment.

Impaled cells were identified as photoreceptors visually and by their responses to light. L-[2,5] $\left[{ }^{3} \mathrm{H}\right]$ histidine was injected into photoreceptor axon hillocks and into ganglion cells. Several photoreceptors and ganglion cells were injected in each of five preparations. Microelectrodes had resistances of $40-50 \mathrm{M} \Omega$ and contained $1.5 \mu \mathrm{l}$ of $\left[{ }^{3} \mathrm{H}\right]$ histidine $(80 \mu \mathrm{M})$ in $400 \mathrm{~mm} \mathrm{KCl}$. [ $\left.{ }^{3} \mathrm{H}\right]$ Histidine was pressure-injected via a Picospritzer (General Valve, Fairfield, NJ) by pulses ranging in duration from short $(30 \mathrm{sec})$ to long $(240 \mathrm{sec})$ at $40-80 \mathrm{psi}$ for $15 \mathrm{~min}$. During the injections, all preparations were stimulated with light. During and after completion of injections, responses to light could be recorded from the photoreceptors and off responses could be recorded from postsynaptic cells. After injection, preparations were either stimulated for $1,5.5$, or $24 \mathrm{hr}$ with light flashes $\left(0.13 \mathrm{~mW} / \mathrm{cm}^{2}, 2 \mathrm{sec}\right.$ on, $5 \mathrm{sec}$ off $)$ or left in the dark for 24 hr before being homogenized. For the shorter incubations ( 1 and $5.5 \mathrm{hr}$ ), preparations were superfused with normal saline $\left(10-15^{\circ} \mathrm{C}\right)$. Preparations incubated for $24 \mathrm{hr}$ were maintained in saline supplemented with glucose $(10 \mathrm{~mm})$ at $9-10^{\circ} \mathrm{C}$.

The median ocellar nerve was severed $\sim 1-2 \mathrm{~mm}$ from the ganglion, dividing the preparation into the ocellus (containing the photoreceptor somata) and nerve (containing the axons) on the one hand, and the
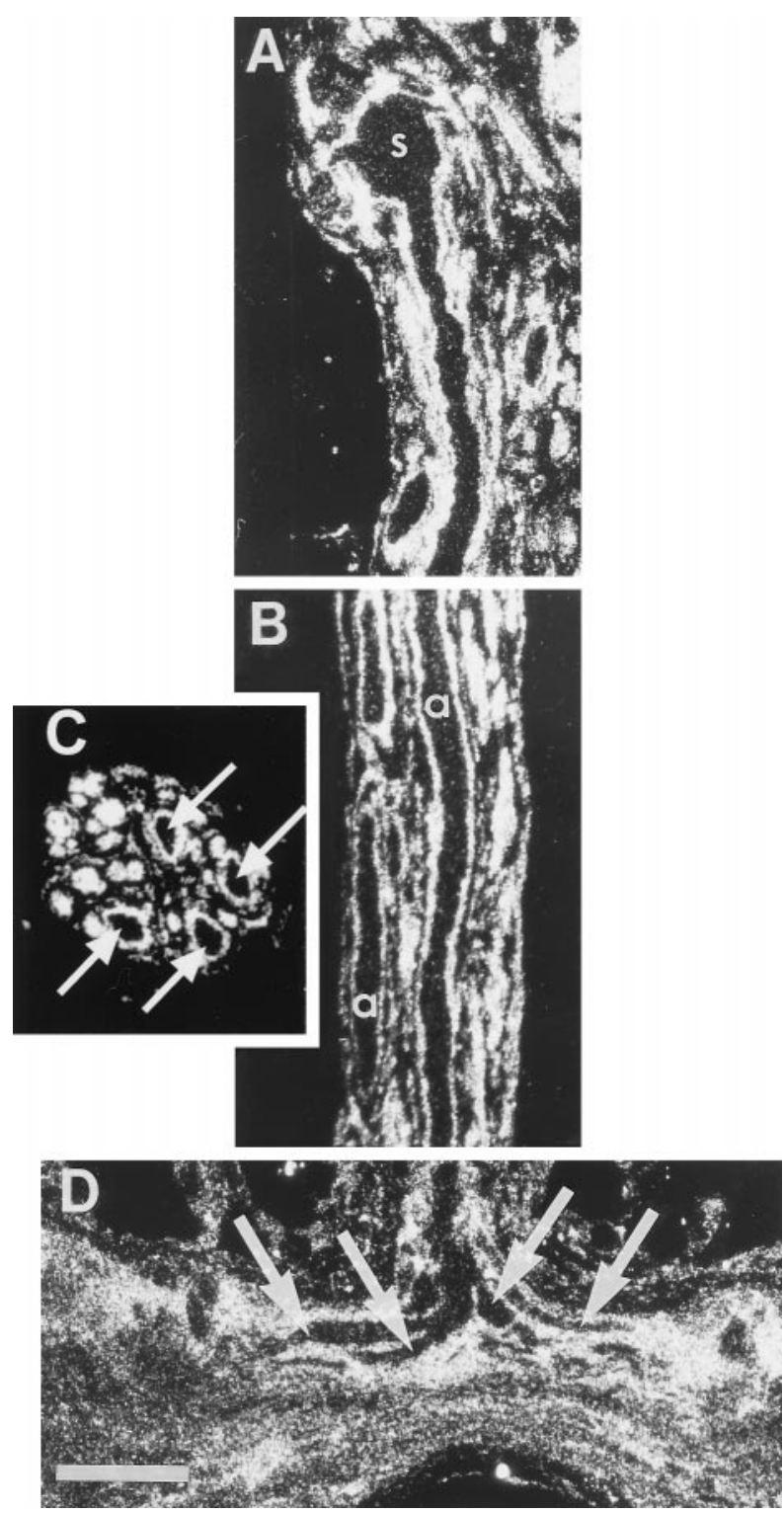

Figure 1. Glia, not photoreceptors, preferentially accumulate $\left[{ }^{3} \mathrm{H}\right] \mathrm{histi}$ dine. Dark-field autoradiographs of sections through preparations that had been incubated in $20 \mu \mathrm{M}\left[{ }^{3} \mathrm{H}\right]$ histidine in flashing light at $15^{\circ} \mathrm{C}$. Silver grains over the glia outline the sparsely labeled photoreceptor profiles in each panel. $A$, Horizontal section through a photoreceptor soma $(s)$ in the median ocellus and the initial portion of its axon in the median ocellar nerve. $B$, Horizontal section through the median ocellar nerve passes through two of the four photoreceptor axons $(a)$. $C$, A cross section through the nerve shows the profiles of the four large, sparsely labeled photoreceptor axons (arrows) ringed by intensely labeled glia; other axons in the nerve are too small to be distinguished from their surrounding glia in cross section. $D$, Horizontal section through the commissure of the supraesophageal ganglion at the midline where the bifurcating primary branches of the presynaptic arbor (arrows) enter. Scale bar: D, $100 \mu \mathrm{m}$ (applies to all panels). 


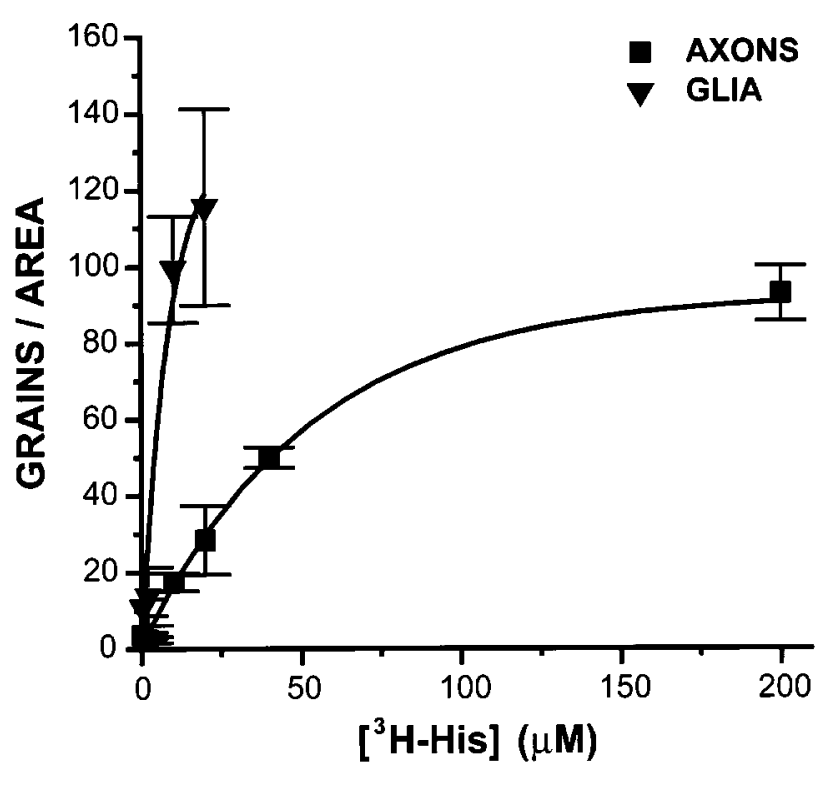

Figure 2. Dependence on concentration of the accumulation of $\left[{ }^{3} \mathrm{H}\right] \mathrm{his}-$ tidine $\left({ }^{3} \mathrm{H}-\mathrm{His}\right)$ in glia and photoreceptors. Ocellar nerves were exposed to $0.2,2,10,20,40$, and $200 \mu \mathrm{M}\left[{ }^{3} \mathrm{H}\right]$ histidine for $15 \mathrm{~min}$ under standard incubation conditions. Glia labeled more heavily than did photoreceptor axons at every concentration tested. Labeling of photoreceptor axons approached saturation at $200 \mu \mathrm{M}\left[{ }^{3} \mathrm{H}\right]$ histidine, exhibiting a $K_{\mathrm{m}}$ of $\sim 50$ $\mu \mathrm{M}$. Glial labeling was too dense to quantify above $20 \mu \mathrm{M}$.

ganglion (containing the photoreceptor terminals and the ganglion cells) on the other. $\left[{ }^{3} \mathrm{H}\right]$ Histamine synthesized during this period was extracted from tissue homogenates and assayed by thin-layer chromatography as described above.

\section{RESULTS}

\section{Accumulation of $\left[{ }^{3} \mathrm{H}\right]$ histidine in photoreceptors, ganglion cells, and glia \\ Photoreceptors label sparsely compared with glia after incubation of preparations in $\left[{ }^{3} H\right]$ histidine}

When preparations $(n=11)$ were incubated for $15 \mathrm{~min}$ in $\left[{ }^{3} \mathrm{H}\right.$ ]histidine $(0.2-200 \mu \mathrm{M} ; 50 \mathrm{Ci} / \mathrm{mmol}$; flashing light) and processed for autoradiography, label accumulated far more intensely over glial cells than over the photoreceptors (Fig. 1). After the $\left[{ }^{3} \mathrm{H}\right]$ histidine incubations, the photoreceptor somata (Fig. 1A), axons (Fig. $1 B, C$ ), and primary branches of the presynaptic arbor (Fig. $1 D$ ) labeled only slightly above background, appearing in dark-field illumination as dark profiles outlined by the brightly reflecting grains over the glia. In cross sections of the nerve (Fig. $1 C$; cf. Hudspeth and Stuart, 1977, their Plates $1 E$ and $3 A$ ), the concentration of grains over the glia ringing the four large, lightly labeled photoreceptors was especially striking. This result was in marked contrast to the highly specific labeling of photoreceptor axons and presynaptic arbors observed when preparations were incubated under similar conditions in $\left[{ }^{3} \mathrm{H}\right]$ histamine $(20 \mu \mathrm{M}$; 36-57 Ci/mmol) (Stuart et al., 1996, their Fig. 1).

Incubation of preparations in $\left[{ }^{3} \mathrm{H}\right]$ histidine for $1 \mathrm{hr}$ instead of 15 min only slightly increased the labeling of the photoreceptors (data not shown). Because intracellular recording from axons shows that bath-applied compounds reach the photoreceptor axons within minutes (Hudspeth et al., 1977), $1 \mathrm{hr}$ should have been ample time to allow the concentration of $\left[{ }^{3} \mathrm{H}\right]$ histidine in the extracellular space to equilibrate with that in the bath. Thus, the pattern of label is unlikely to be caused by accumulation by

\begin{tabular}{|c|c|c|c|}
\hline Prep & PR soma & PR axons & Ganglion cells \\
\hline A $200 \mu \mathrm{M}$ & $133 \pm 10.2$ & $\begin{aligned} \mathrm{A} 1-91 & \pm 9.4 \\
\mathrm{~A} 2-130 & \pm 10.3 \\
\mathrm{~A} 3-111 & \pm 4.7\end{aligned}$ & $\begin{array}{l}\text { GC1-105 } \\
\text { GC2-107 }\end{array}$ \\
\hline B $200 \mu \mathrm{M}$ & $128 \pm 4.5$ & Not counted & $\begin{array}{l}\text { GC1-143 } \pm 12.8 \\
\text { GC2-130 } \pm 12.7\end{array}$ \\
\hline C $200 \mu \mathrm{M}$ & $96 \pm 25.1$ & $\begin{array}{l}\text { A1-69 } \pm 8.9 \\
\text { A2-90 } \pm 7.8 \\
\text { A3-70 } \pm 3.4\end{array}$ & $\begin{array}{l}\text { GC1-120 } \\
\text { GC2-86 } \\
\text { GC3-123 } \\
\text { GC4-132 } \\
\text { GC5-123 } \\
\text { GC6-98 } \\
\text { GC7-103 }\end{array}$ \\
\hline D $20 \mu \mathrm{M}$ & $53 \pm 6.4$ & $\begin{array}{l}\mathrm{A} 1-25 \pm 5.9 \\
\mathrm{~A} 2-53 \pm 6.9\end{array}$ & $\begin{array}{l}\text { GC1-26 } \\
\text { GC2-43 } \\
\text { GC3-65 } \\
\text { GC4-61 } \\
\text { GC5-57 } \\
\text { GC6-51 } \\
\text { GC7-49 } \\
\text { GC8-55 } \\
\text { GC9-17 } \\
\text { GC10-48 } \\
\text { GC11-29 } \\
\text { GC12-57 }\end{array}$ \\
\hline
\end{tabular}

$\overline{{ }^{a} \text { When SDs are shown, counts were averaged from several cytoplasmic areas within }}$ the cell. When counts were expressed without SDs, only one area was available for counting.

the glia of the $\left[{ }^{3} \mathrm{H}\right]$ histidine before it had access to the photoreceptors.

It was not possible to determine whether label was highly localized at the release sites in the presynaptic arbors of the photoreceptors because these small, distal branches are intermingled with neuronal and glial processes in a neuropil (Hudspeth and Stuart, 1977; Schnapp and Stuart, 1983; Callaway et al., 1993). However, the visible primary branches of the arbor (Fig. $1 D)$ did not label more heavily than other regions of the photoreceptor (Fig. $1 A, B$ ), and we saw no dramatic increase in label in the area of the ganglion where the most distal branches containing the release sites are located. This is in contrast to the intense label seen in the presynaptic arbor after $\left[{ }^{3} \mathrm{H}\right]$ histamine incubation (Stuart et al., 1996). It seems unlikely, then, that $\left[{ }^{3} \mathrm{H}\right]$ histidine is taken up selectively at the presynaptic sites of the photoreceptors.

Labeling of both glia and photoreceptors increased with increasing $\left[{ }^{3} \mathrm{H}\right]$ histidine concentration $(0.2-200 \mu \mathrm{M})$; photoreceptor grain densities approached saturation at $200 \mu \mathrm{M}$ (Fig. 2). The $K_{\mathrm{m}}$ of the histidine carrier in the photoreceptors was estimated to be $\sim 50 \mu \mathrm{M}$. The glial label was too dense to quantify at the higher concentrations. Incubation in $\mathrm{Na}^{+}$-free saline $\left(\mathrm{Na}^{+}\right.$replaced with tetramethylammonium ion) reduced the labeling of the photoreceptor axons (but not the glia) to background levels $(n=2)$. Incubation in $\left[{ }^{3} \mathrm{H}\right]$ histidine and an excess of unlabeled histidine ( $1 \mathrm{~mm}$ ) decreased the labeling of the photoreceptors to $\sim 25 \%$ of that of controls.

Because much more precursor of the transmitter of the photoreceptor was taken up into glia than into the photoreceptors 

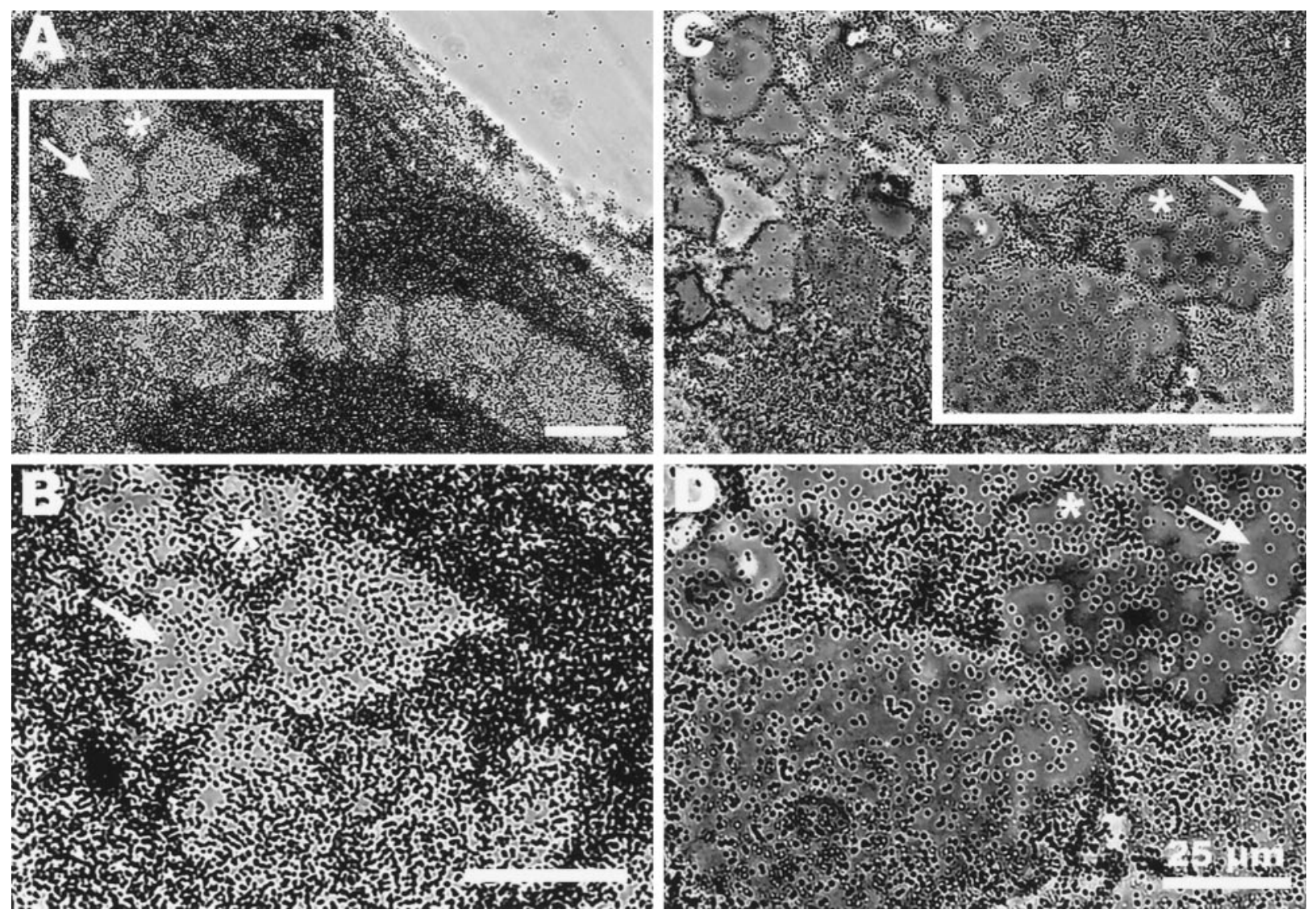

Figure 3. Ganglion cell bodies, like photoreceptors, label sparsely compared with glia in preparations incubated in [ $\left.{ }^{3} \mathrm{H}\right]$ histidine. Autoradiographs of horizontal sections through portions of two ganglia incubated in $200 \mu \mathrm{M}(A, B)$ or $20 \mu \mathrm{M}(C, D)\left[{ }^{3} \mathrm{H}\right]$ histidine shown in phase-contrast illumination. Groups of ganglion cell bodies from boxed areas in $A$ and $C$ are shown at higher power in $B$ and $D$. For orientation, asterisks identify the same neuron in each set of photographs. Grains are primarily concentrated over glial cells; ganglion cells label more sparsely, like the photoreceptors. There are differences in the degree of labeling of the ganglion cells, more obvious in the $20 \mu \mathrm{M}$-incubated preparations; cells with fewer grains are marked by arrows. Scale bars, $25 \mu \mathrm{M}$.

themselves and because photoreceptors have a high-affinity uptake mechanism for the transmitter itself (histamine) even on their axons (Stuart et al., 1996), we wondered whether the transmitter might be synthesized in the glia and then shipped to the photoreceptors. To rule out this possibility, we flooded preparations with unlabeled histamine (1 mM; Stuart et al., 1996) to block competitively the uptake into photoreceptors of any labeled transmitter $\left(\left[{ }^{3} \mathrm{H}\right]\right.$ histamine $)$ that might have been synthesized in glia and released into the space between the glia and the photoreceptors. The labeling of the photoreceptor axons was not reduced (data not shown; $n=4$ ), arguing that the grains in the photoreceptors represent the uptake of $\left[{ }^{3} \mathrm{H}\right]$ histidine, not $\left[{ }^{3} \mathrm{H}\right]$ histamine transferred from glia to photoreceptors.

\section{Photoreceptors and nonhistaminergic neurons label equally after incubation in $\left[^{3} H\right]$ histidine}

We examined the accumulation of $\left[{ }^{3} \mathrm{H}\right]$ histidine by (nonhistaminergic) ganglion cells in sections through the ganglion. Grain counts from three preparations incubated in $200 \mu \mathrm{M}$ and one in 20 $\mu \mathrm{M}\left[{ }^{3} \mathrm{H}\right]$ histidine showed that the somata of ganglion cells labeled to about the same extent as the photoreceptors (Table 1; Fig. 3). Preparations incubated in $20 \mu \mathrm{M}\left[{ }^{3} \mathrm{H}\right]$ histidine showed greater variability among ganglion cells in the accumulation of label than those incubated at the higher concentration, but the labeling of the photoreceptors fell within this range. The low rate of accu- mulation of label in neurons is not particularly surprising because neurons do not divide and, consequently, might be expected to accumulate amino acids used in protein synthesis less avidly than dividing glia. The similar rate of accumulation by histaminergic photoreceptors is one indication that these neurons are not specialized to replenish released transmitter by a high rate of synthesis.

\section{Cellular localization of label $24 \mathrm{hr}$ after incubation in $\left[{ }^{3} H\right]$ histidine}

We determined the location of label in preparations that had been pulsed with $\left[{ }^{3} \mathrm{H}\right]$ histidine $(20 \mu \mathrm{M}, 15 \mathrm{~min})$, then chased for up to $24 \mathrm{hr}$ with normal saline. Labeling of glia was always greater than the labeling of photoreceptors (Fig. 4). Thus, the $\left[{ }^{3} \mathrm{H}\right]$ histidine taken up into the glia is not transferred to any great extent to the photoreceptor axons in $24 \mathrm{hr}$. Photoreceptor somata tended to label more heavily than axons. This difference was independent of concentration and persisted over time (Fig. 5).

\section{The accumulation of $\left[{ }^{3} \mathrm{H}\right]$ histidine is not activity-dependent}

The accumulation of $\left[{ }^{3} \mathrm{H}\right]$ histidine is not measurably affected by the level of activity of the photoreceptors (Fig. 6). Preparations incubated in $\left[{ }^{3} \mathrm{H}\right]$ histidine in the dark $(n=3)$ showed no marked difference in the labeling of either glia or photoreceptor somata from those incubated in the light $(n=4)$. In contrast, the uptake 

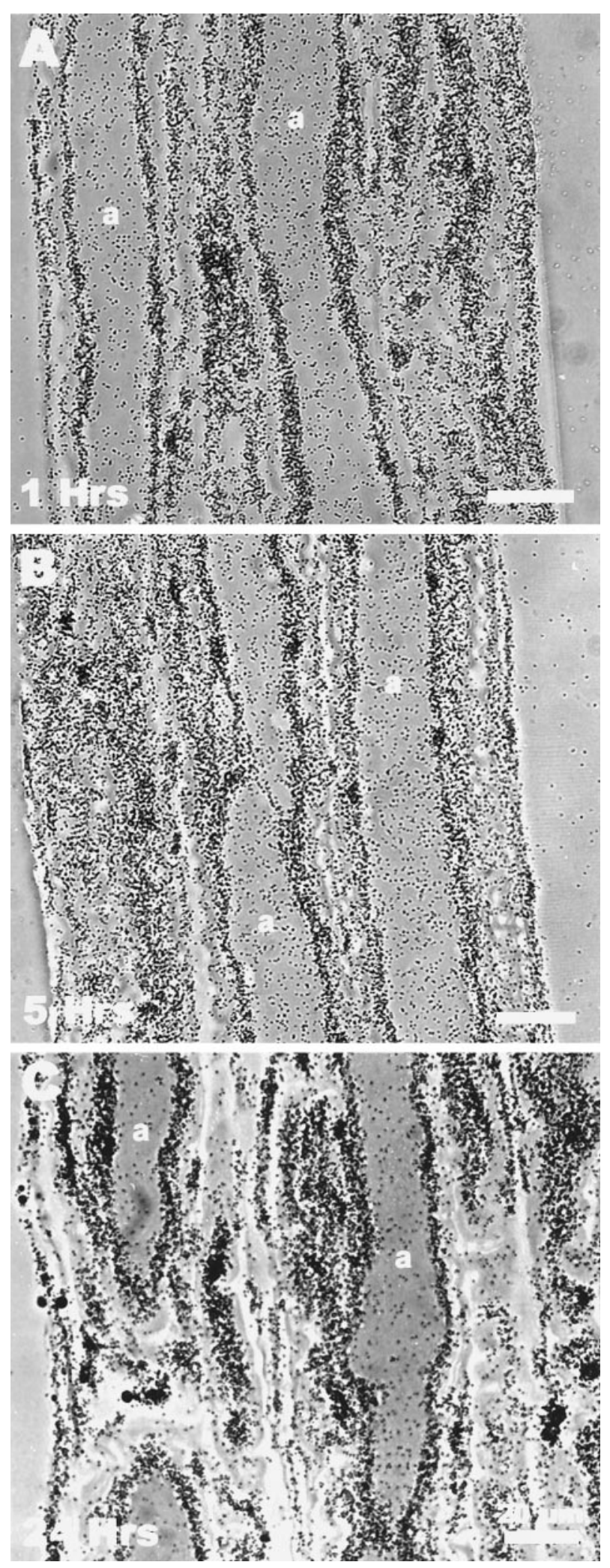

Figure 4. Labeling of photoreceptors does not increase markedly during the $24 \mathrm{hr}$ after a pulse of $\left[{ }^{3} \mathrm{H}\right]$ histidine. Preparations were incubated for $15 \mathrm{~min}$ in $\left[{ }^{3} \mathrm{H}\right]$ histidine and then maintained in normal saline for $1(A)$, $5(B)$, or $24(C) \mathrm{hr}$ before processing the preparation for autoradiography. Photomicrographs of axons at each time period show that even after $24 \mathrm{hr}$ the glia were more heavily labeled than the photoreceptors. Labeling of neither the photoreceptor somata nor their axons increased significantly over the $24 \mathrm{hr}$. Scale bars, $20 \mu \mathrm{m}$. of $\left[{ }^{3} \mathrm{H}\right]$ histamine itself does depend on activity in this time frame; preparations incubated in $\left[{ }^{3} \mathrm{H}\right]$ histamine accumulated more label over photoreceptors when incubated in the light and more label over glia when incubated in the dark (Stuart et al., 1996).

\section{Attempts to deplete histamine lead to increased photoreceptor labeling}

We attempted to increase the demand for histamine synthesis in the photoreceptors by increasing release of the transmitter and, at the same time, blocking its reuptake. Incubations with $\left[{ }^{3} \mathrm{H}\right]$ histidine were performed in a high concentration of $\mathrm{K}^{+}(100 \mathrm{mM}$; Stuart and Callaway, 1991) to stimulate release of endogenous histamine by depolarizing the photoreceptors. Chlorpromazine $(20 \mu \mathrm{M})$ was included in the incubation saline to antagonize $\left[{ }^{3} \mathrm{H}\right]$ histamine uptake (Stuart et al., 1996). Although this drug is only a partial antagonist, it is the most effective blocker known at present. Grain densities counted over photoreceptor somata increased under these conditions (Fig. 7). This result suggests that these manipulations increase the requirement for histidine of the photoreceptor.

\section{Synthesis of $\left[{ }^{3} \mathrm{H}\right]$ histamine \\ Stimulation with light does not increase $\left[{ }^{3} H\right]$ histamine synthesis}

In autoradiography, we could not know whether label was in $\left[{ }^{3} \mathrm{H}\right]$ histidine or $\left[{ }^{3} \mathrm{H}\right]$ histamine. Previous results (Callaway and Stuart, 1989, their Fig. 1) showed that median ocelli (but not ganglia) incubated in $5 \mu \mathrm{M}\left[{ }^{3} \mathrm{H}\right]$ histidine for $17 \mathrm{hr}$ in the dark converted $\sim 1 \%$ of precursor in the homogenate to $\left[{ }^{3} \mathrm{H}\right]$ histamine. We undertook experiments to determine whether stimulation of the photoreceptors with light (which increases the release of transmitter) noticeably accelerated the conversion of the $\left[{ }^{3} \mathrm{H}\right]$ histidine to $\left[{ }^{3} \mathrm{H}\right]$ histamine.

Four preparations were placed in a well together and pulsed with $\left[{ }^{3} \mathrm{H}\right]$ histidine $(20 \mu \mathrm{M})$ for $15 \mathrm{~min}$. After thorough washing, the preparations were either homogenized immediately or were stimulated with light in normal saline (at $15^{\circ} \mathrm{C}$ ) for 1,5 , or $24 \mathrm{hr}$ before homogenization. The homogenates were centrifuged, and labeled compounds in the supernatants were separated by thinlayer chromatography (Fig. $8 A$ ).

Vastly more $\left[{ }^{3} \mathrm{H}\right]$ histidine than $\left[{ }^{3} \mathrm{H}\right]$ histamine was found in the preparation even $24 \mathrm{hr}$ after the pulse (Fig. 8B). Although $\left[{ }^{3} \mathrm{H}\right]$ histamine was synthesized, the radioactivity in the $\left[{ }^{3} \mathrm{H}\right]$ histamine peak was only $\sim 0.5 \%$ of the total radioactivity in the combined histidine and histamine peaks. No other significant peaks of radioactivity were present in the chromatograph that might have been $\left[{ }^{3} \mathrm{H}\right]$ histamine metabolites (Fig. $8 A$ ). Because most of the $\left[{ }^{3} \mathrm{H}\right]$ histidine taken up is in the glia (from autoradiography), we cannot know what proportion of the $\left[{ }^{3} \mathrm{H}\right]$ histidine taken up into the photoreceptors was synthesized into $\left[{ }^{3} \mathrm{H}\right]$ histamine.

In several other experiments, one or two preparations were supplied with $\left[{ }^{3} \mathrm{H}\right]$ histidine $(20 \mu \mathrm{M})$ for the entire duration of a 23 $\mathrm{hr}$ incubation in flashing light, and labeled compounds from homogenized ganglia were separated by thin-layer chromatography. In six experiments, $\left[{ }^{3} \mathrm{H}\right]$ histamine comprised at most $2 \%$ of the total $\left[{ }^{3} \mathrm{H}\right]$ histamine plus $\left[{ }^{3} \mathrm{H}\right]$ histidine in the homogenate. In these experiments there was also no detectable $\left[{ }^{3} \mathrm{H}\right]$ histamine in the medium. Release of synthesized $\left[{ }^{3} \mathrm{H}\right]$ histamine that was not recaptured would have caused us to underestimate the amount of $\left[{ }^{3}\right.$ H]histamine synthesized.

Thus, stimulation with light does not substantially increase the 


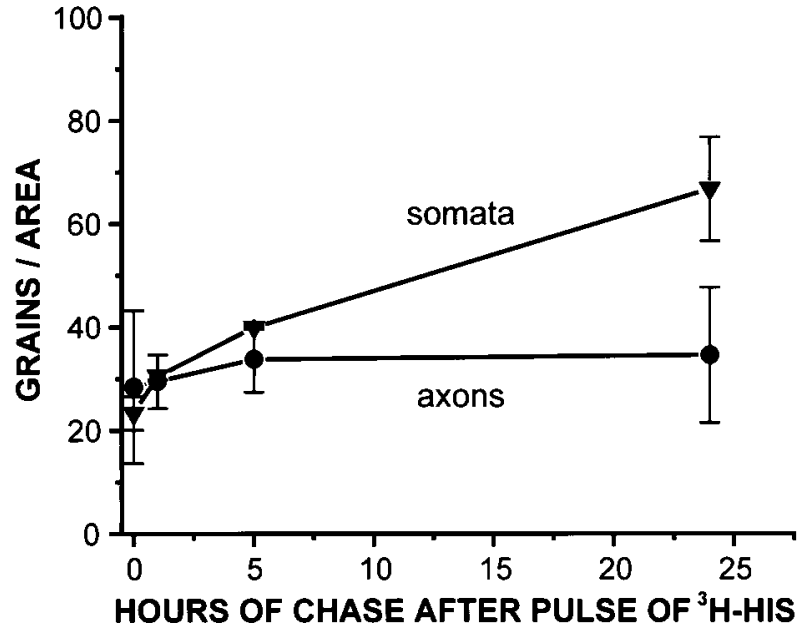

Figure 5. Photoreceptor somata label more heavily than axons. Preparations were incubated for $15 \mathrm{~min}$ in $\left[{ }^{3} \mathrm{H}\right]$ histidine and then either fixed immediately or maintained in normal saline for 1,5 , or $24 \mathrm{hr}$ before processing for autoradiography. Photomicrographs of somata and axons taken at each time period show that labeling of the somata increases more dramatically than the axons over the $24 \mathrm{hr}$ period ( 1 and $5 \mathrm{hr}$ incubations, $n=5 ; 24 \mathrm{hr}$ incubation, $n=3$ ).

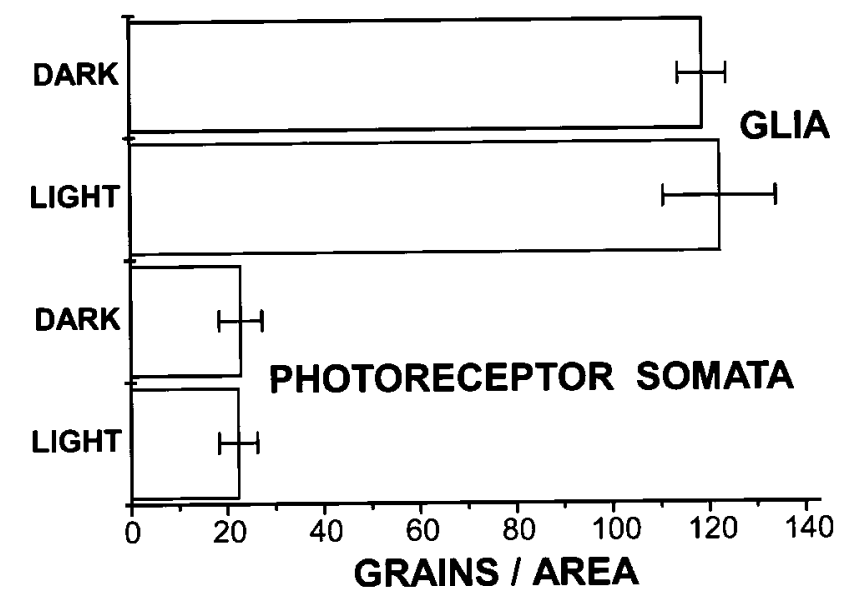

Figure 6. Accumulation of label in glia and in photoreceptor somata is not significantly different in light-stimulated and dark conditions. Preparations were incubated in $\left[{ }^{3} \mathrm{H}\right]$ histidine for $15 \mathrm{~min}$ at $15^{\circ} \mathrm{C}$ and either stimulated with flashing light $(n=3)$ or maintained for that time in the dark $(n=4)$. The incubations were terminated, and the illumination or dark condition was maintained while the ganglia were being washed before fixation. After autoradiography, sections of the nerve were photographed, and the grains within an area of $254 \mu \mathrm{m}^{2}$ were counted (see Materials and Methods). No significant differences in labeling were detected between the two conditions.

rate of synthesis of $\left[{ }^{3} \mathrm{H}\right]$ histamine from accumulated $\left[{ }^{3} \mathrm{H}\right]$ histidine in whole preparations. Because only a small fraction of the radioactivity is in the photoreceptors, however, stimulation might indeed accelerate synthesis within the photoreceptors, but this effect may go undetected. Thus, in one set of experiments, we injected $\left[{ }^{3} \mathrm{H}\right]$ histidine into individual photoreceptor neurons and assayed for $\left[{ }^{3} \mathrm{H}\right]$ histamine synthesis in the light and in the dark.

\section{Injection of $\left[{ }^{3} H\right]$ histidine into photoreceptors}

$\left[{ }^{3} \mathrm{H}\right]$ histidine was injected into the axon hillocks of photoreceptors and into ganglion cells. After injection, preparations were maintained in flashing light or in the dark for $1,5.5$, or $24 \mathrm{hr}$

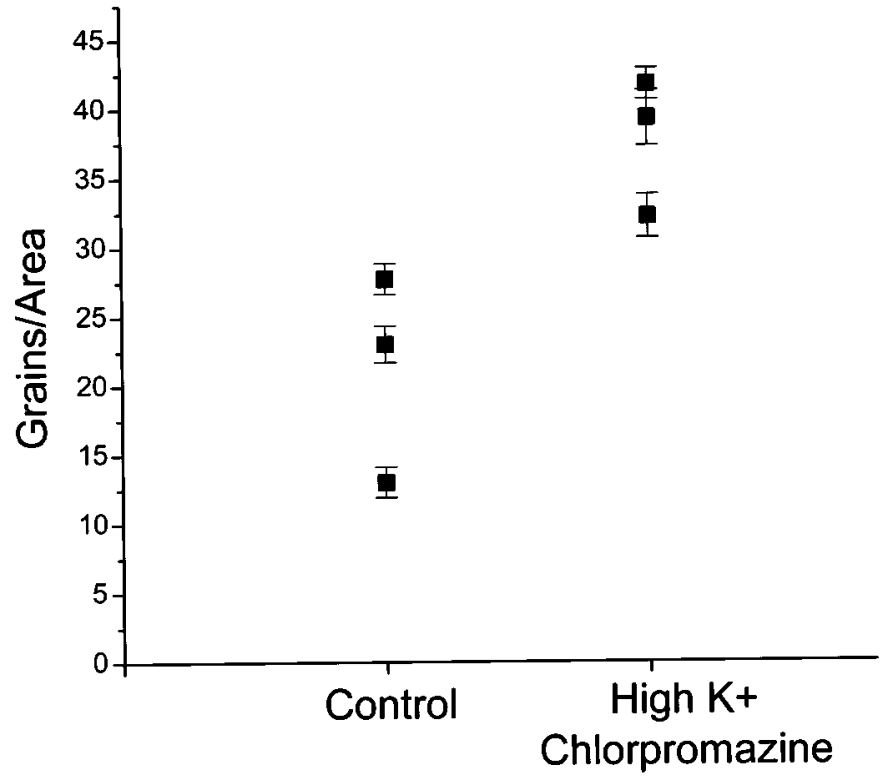

Figure 7. Conditions expected to deplete photoreceptors of histamine increase their uptake of $\left[{ }^{3} \mathrm{H}\right]$ histidine. Preparations were preincubated in high $\mathrm{K}^{+}(100 \mathrm{mM})$ to stimulate histamine release and chlorpromazine (20 $\mu \mathrm{M})$ to decrease HA reuptake. After a $5 \mathrm{~min}$ wash in normal saline, preparations were incubated in $20 \mu \mathrm{M}\left[{ }^{3} \mathrm{H}\right]$ histidine under standard conditions. Somata of "depleted" preparations $(n=3)$ showed an increase in grain density over controls $(n=3)$. Each time point is the average of four to six areas counted within a photoreceptor soma for each preparation.

$\left(10^{\circ} \mathrm{C}\right)$, then homogenized and assayed by thin-layer chromatography to determine how much $\left[{ }^{3} \mathrm{H}\right]$ histamine was synthesized from the injected precursor.

Although the number of counts that could be injected into cells was small, $\left[{ }^{3} \mathrm{H}\right]$ histamine was clearly synthesized by the photoreceptors but not by the ganglion cells (Fig. 9). The major peak of radioactivity ran with $\left[{ }^{3} \mathrm{H}\right]$ histidine even $24 \mathrm{hr}$ after the injection of $\left[{ }^{3} \mathrm{H}\right]$ histidine. The percentage of the injected counts converted to $\left[{ }^{3} \mathrm{H}\right]$ histamine was roughly similar after $24 \mathrm{hr}$ regardless of whether the preparation was maintained in the dark or stimulated continuously with flashing light (Fig. 9). These results show that $\left[{ }^{3} \mathrm{H}\right]$ histamine is synthesized in the photoreceptors themselves, that uptake of $\left[{ }^{3} \mathrm{H}\right]$ histidine is not rate limiting in the synthesis pathway, and that the rate of synthesis is not affected in a dramatic way by stimulation of the cell with light.

\section{DISCUSSION}

Maintenance of the transmitter pool in a histaminergic photoreceptor involves two pathways: de novo synthesis of histamine from histidine and recapture of released histamine. The present experiments show, first, that the synthetic pathway occurs within the photoreceptor itself and not in the glia. Intracellular injection of labeled precursor shows directly that histamine is indeed synthesized in photoreceptors. This result agrees with previous results showing that glia do not label with an anti-histamine antibody that labels photoreceptors clearly (Callaway et al., 1989; Sarthy, 1991).

Furthermore, the present results indicate that synthesis is unlikely to be the primary pathway in the maintenance of the histamine pool in barnacle photoreceptors. Neither the uptake of precursor nor the synthesis of transmitter is affected by conditions of light and dark. Because the uptake of labeled histamine itself 

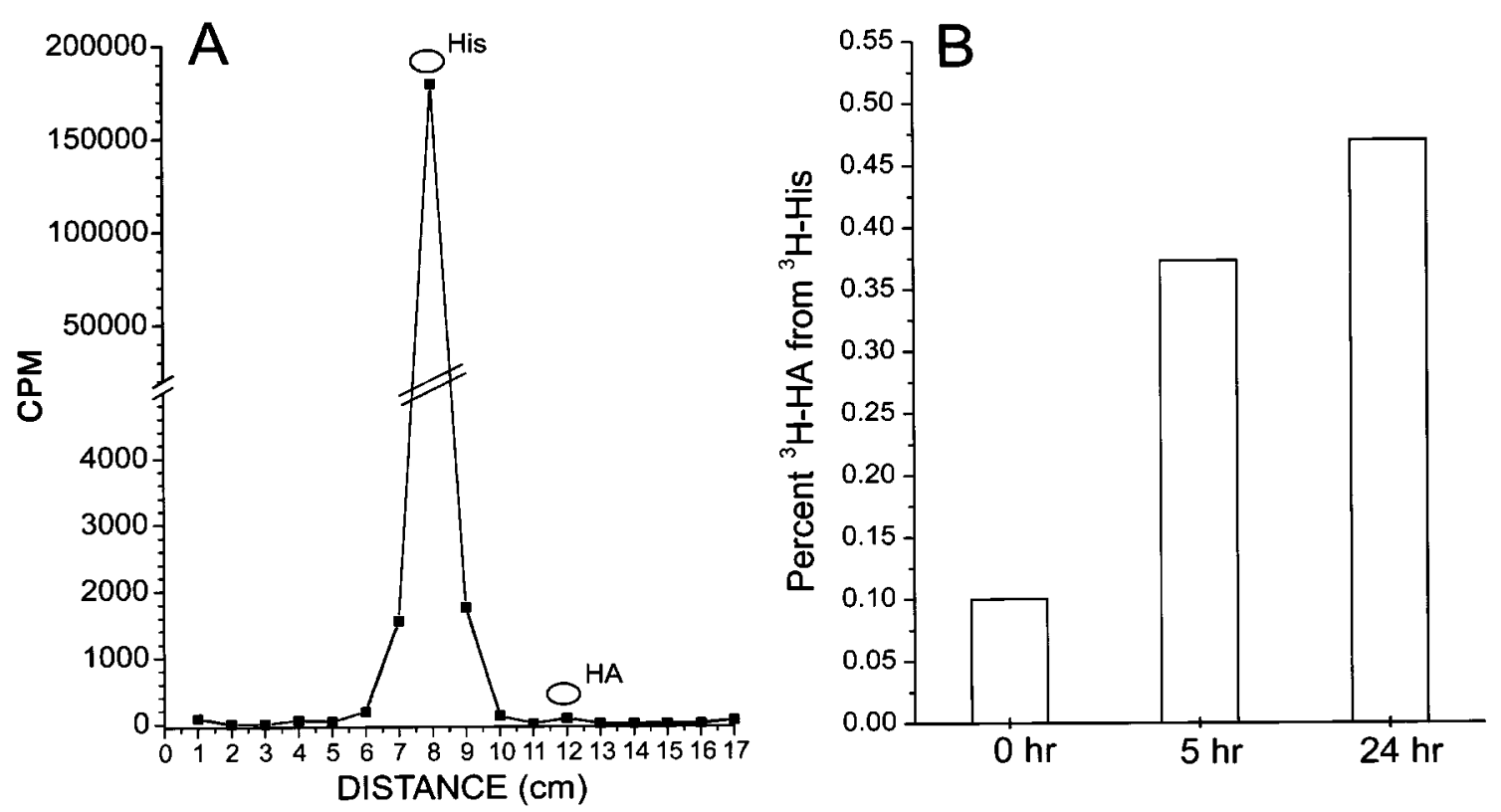

Figure 8. Little $\left[{ }^{3} \mathrm{H}\right]$ histamine is found in the tissue up to $24 \mathrm{hr}$ after a pulse of $\left[{ }^{3} \mathrm{H}\right]$ histidine. Four preparations were incubated in $20 \mu \mathrm{M}\left[{ }^{3} \mathrm{H}\right]$ histidine $\left({ }^{3} \mathrm{H}\right.$-His $)\left(15 \mathrm{~min}, 15^{\circ} \mathrm{C}\right.$, flashing light), washed in normal saline, then further maintained at $15^{\circ} \mathrm{C}$ in flashing light until homogenization 0,5 , or 24 hr later. Homogenates were centrifuged, and $\left[{ }^{3} \mathrm{H}\right]$ histidine was separated from $\left[{ }^{3} \mathrm{H}\right]$ histamine by thin-layer chromatography. $A$, A chromatograph of the extract of preparations homogenized at $t=0$ shows that radioactivity in the tissue is primarily $\left[{ }^{3} \mathrm{H}\right]$ histidine. A large peak of radioactivity runs with an unlabeled histidine standard, and there are no other significant peaks of radioactivity. $B$, Labeled histamine $\left({ }^{3} H-H A\right)$, as a percent of the total counts in the $\left[{ }^{3} \mathrm{H}\right]$ histidine and $\left[{ }^{3} \mathrm{H}\right]$ histamine peaks, separated by TLC from preparations homogenized at $t=0$ (immediately after incubation) and at 5 and 24 hr. Even at $24 \mathrm{hr},\left[{ }^{3} \mathrm{H}\right]$ histamine is $<0.5 \%$ of the total counts in these peaks.

has been shown to be avid, specific, and affected by light and dark conditions (Stuart et al., 1996), it is more likely that recapture is the primary mechanism for maintaining the transmitter supply. In agreement with this conclusion, when we took steps designed to deplete the transmitter pool (antagonizing uptake and stimulating transmitter release with high $\mathrm{K}^{+}$saline), the grain density in the photoreceptors increased as if these manipulations upregulated the synthetic pathway.

These results parallel evidence that vertebrate photoreceptors do not rely on the uptake of the precursor glutamine for maintaining the supply of their neurotransmitter glutamate. Photoreceptors show no immunoreactivity to the precursor of glutamate, glutamine (Pow and Crook, 1996), and they maintain their immunoreactivity to glutamate even when glutamine levels in the tissue are decreased by blocking its synthesis (in glia) (Pow and Robinson, 1994). Vertebrate photoreceptors can take up glutamate into their presynaptic terminals (Marc and Lam, 1981; Tachibana and Kaneko, 1988; Eliasof and Werblin, 1993; Arriza et al., 1997), and it is presumably this uptake process that primarily maintains the transmitter pool. In this respect, vertebrate photoreceptors differ from retinal ganglion cells, which rely on the import of glutamine from stores in glial cells to maintain their supply of glutamate (Pow and Robinson, 1994).

\section{Histidine uptake}

The precursor histidine is not accumulated preferentially by the photoreceptors. Labeled histidine is accumulated and stored primarily in glia; both the histaminergic photoreceptors and the nonhistaminergic neurons of the ganglion accumulate so little histidine in comparison that they appear in dark-field as black profiles surrounded by the white glial label. This lack of difference between histaminergic and nonhistaminergic cells is perhaps not surprising because histidine is an amino acid used in protein synthesis. Isolated histaminergic and nonhistaminergic cells from Aplysia also did not differ in histidine accumulation (Weinreich and $\mathrm{Yu}, 1977)$. On the other hand, studies using rat brain synaptosomes have concluded that there is a high-affinity histidine uptake mechanism localized to histaminergic cells or nerve terminals in mammalian CNS. High-affinity histidine transport was shown to be greater in synaptosomes from hypothalamus, where histaminergic cells reside, than in those from other brain regions (Chudomelka and Murrin, 1983; Hegstrand and Simon, 1985).

As in Aplysia, in the present experiments $\left[{ }^{3} \mathrm{H}\right]$ histidine at any concentration did not accumulate in the photoreceptors, even in the primary branches of their presynaptic arbors, more intensely than in other (nonhistaminergic) neurons. If histidine uptake were localized, such localization would have to be at the extreme tips of the arbor that are in a neuropil, entwined with glia, and thus not separately visible. This situation seems to us unlikely because there was no increase in grain density where these distal terminals are found in the ganglion. In addition, because histamine itself is found (using an anti-histamine antibody) throughout the terminal branches of the photoreceptors, even well up into their axons, we expected that any highly localized uptake of labeled precursor would appear as an increase of grain density in this part of the neuron. No such increase was seen (Fig. 1D).

For some transmitters, for example glutamate, the uptake of precursor is a regulatory step in transmitter synthesis (Hamberger et al., 1979). For histamine synthesis in the mammalian CNS, histidine transport is unlikely to play a regulatory role because depolarization of synaptosomes with high $\mathrm{K}^{+}$does not accelerate synthesis (Chudomelka and Murrin, 1983; Hegstrand and Simon, 1985). The present results also argue that histidine uptake in this arthropod photoreceptor is not regulated by activity: there was no major change in autoradiographic labeling of the 


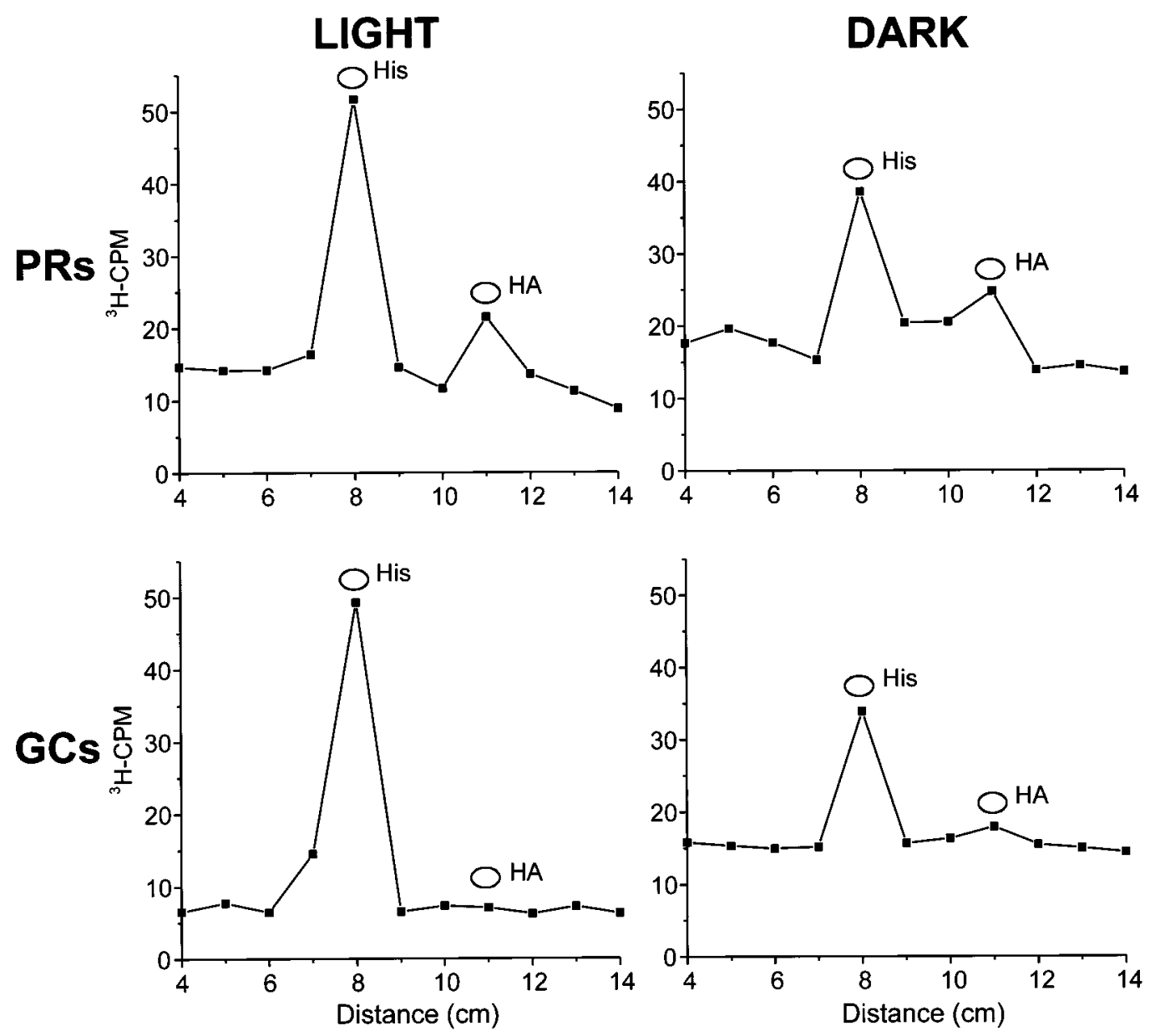

Figure 9. The rate of synthesis of $\left[{ }^{3} \mathrm{H}\right]$ histamine from injected $\left[{ }^{3} \mathrm{H}\right]$ histidine is not significantly increased by stimulating preparations with light. Two to four photoreceptors and five to seven ganglion cells within each preparation were injected with $\left[{ }^{3} \mathrm{H}\right]$ histidine and then incubated in normal saline with $10 \mathrm{~mm}$ glucose at $9-10^{\circ} \mathrm{C}$ for $24 \mathrm{hr}$ in either flashing light or in the dark. The $\left[{ }^{3} \mathrm{H}\right]$ histidine was separated from the [ $\left.{ }^{3} \mathrm{H}\right]$ histamine by thin-layer chromatography. Peaks of radioactivity ran with the cold histidine and histamine standards in both the photoreceptor and the ganglion chromatographs in both light and the dark conditions. The ratio of labeled histamine to labeled histidine was not significantly different in the light or the dark incubations. No significant peaks of radioactivity ran with the cold histamine standards in the nonhistaminergic ganglion cell chromatographs. There were no other significant peaks of radioactivity.

photoreceptors between conditions of light (when the photoreceptors are depolarized and releasing transmitter) or dark.

\section{Histamine synthesis}

The rate of synthesis is roughly what one would expect from a transmitter whose precursor is an amino acid used in protein synthesis; there seems to be no specialization in the synthetic pathway accompanying the specialized nature of the synapse of the photoreceptor, which releases transmitter continuously. In addition, the conversion of histidine to histamine rather than the import of histidine appears to be the rate-limiting step in the synthetic pathway. The percentage of $\left[{ }^{3} \mathrm{H}\right]$ histidine converted to histamine by barnacle eyes during long (17-24 hr) incubations was small (0.5-2\%) whether the preparation was in flashing light or in the dark (1-5\%; Callaway and Stuart, 1989). Likewise, Sarthy (1991) found only $1-2 \%$ conversion of $\left[{ }^{3} \mathrm{H}\right]$ histidine to $\left[{ }^{3} \mathrm{H}\right]$ histamine by Drosophila heads during $5 \mathrm{hr}$ incubations. These values must underestimate the rate of synthesis by the photoreceptors because when precursor is provided in the medium, $\left[{ }^{3} \mathrm{H}\right]$ histidine is mainly taken up by glia in both species and not further converted to $\left[{ }^{3} \mathrm{H}\right]$ histamine. Indeed, somewhat greater conversion (12\%) was found for locust retina by Elias and Evans (1983) where photoreceptors form a greater proportion of the total cellular mass in the tissue (Sarthy, 1991).

When examined directly by injection of $\left[{ }^{3} \mathrm{H}\right]$ histidine into neurons, synthesis of $\left[{ }^{3} \mathrm{H}\right]$ histamine in the photoreceptors parallels synthesis in histaminergic cells from other species. Intracellular injections of $\left[{ }^{3} \mathrm{H}\right]$ histidine into the histaminergic ganglion cell C2 of Aplysia (Schwartz et al., 1986) showed that $\sim 16 \%$ of the total counts injected were found in $\left[{ }^{3} \mathrm{H}\right]$ histamine after a $1 \mathrm{hr}$ incubation. Injections of $\left[{ }^{3} \mathrm{H}\right]$ histidine into barnacle photoreceptors show in $1 \mathrm{hr} \sim 8 \%$, and in $24 \mathrm{hr} \sim 20-25 \%$, of the total counts to be in $\left[{ }^{3} \mathrm{H}\right]$ histamine. In contrast, in certain other transmitter systems synthesis is much more rapid. For example, inhibition of synthesis of glutamate in retinal ganglion cells by blocking synthesis of its precursor glutamine for $90 \mathrm{~min}$ can totally deplete these cells of transmitter, assayed immunohistochemically. Our biochemical results agree with the autoradiography in suggesting that histamine synthesis is relatively unimportant in maintaining presynaptic transmitter pools compared with transmitter recycling. 


\section{Blocking histamine uptake}

Attempts to drive the synthesis of $\left[{ }^{3} \mathrm{H}\right]$ histamine in the photoreceptors during $\left[{ }^{3} \mathrm{H}\right]$ histidine incubations (by stimulating transmitter release and antagonizing uptake) doubled the autoradiographic labeling of the photoreceptors. Whether doubling is a large or small change depends on two factors that we do not know: whether the label is in histidine or histamine and the size of the endogenous precursor and transmitter pools. In addition, the effect may be only small compared with what we might observe if uptake were completely blocked because chlorpromazine only partially blocks uptake (Stuart et al., 1996). We also do not know what effect depolarization of the glia by the high $\mathrm{K}^{+}$ concentration would have on efflux of the $\left[{ }^{3} \mathrm{H}\right]$ histidine accumulated in these cells; reversed $\left[{ }^{3} \mathrm{H}\right]$ histidine transport from glia into the extracellular space might lead to increased photoreceptor labeling. Nevertheless, blocking histamine uptake and stimulating release increase the uptake of precursor by the photoreceptors.

\section{Glia}

At the outset of these experiments, when $\left[{ }^{3} \mathrm{H}\right]$ histidine was found to accumulate in glia so intensely, we wondered if glia were involved in the transmitter cycle. It is well established that glia are a key step in the synthesis of glutamate and they are suspected to be involved in supplying precursor for the synthesis of other transmitters as well (Martin, 1992; Pow and Crook, 1997). In barnacle photoreceptors, however, glia do not appear to be involved in the transmitter cycle despite their accumulation of $\left[{ }^{3} \mathrm{H}\right]$ histidine. There is not the significant movement of label from glia to photoreceptor axons, over time, that one might expect if synthesis maintained the transmitter pool and the glia supplied precursor to the synthetic pathway (c.f. Pow and Robinson, 1994). Furthermore, unlabeled histamine added in high concentration to the incubation medium did not affect the labeling of the photoreceptor axons as it would have, due to competition for the presumed histamine transporter, if histamine had been synthesized in the glia and transferred to the photoreceptors.

Taken in their entirety, the present observations lead us to conclude that uptake is the primary process replenishing the transmitter supply in barnacle photoreceptors and that the contribution of de novo synthesis is small by comparison even during activity.

\section{REFERENCES}

Arriza JL, Eliasof S, Kavanaugh MP, Amara SG (1997) Excitatory amino acid transporter 5 , a retinal glutamate transporter coupled to a chloride conductance. Proc Natl Acad Sci USA 94:4155-4160.

Battelle B-A, Calman BG, Andrews AW, Grieco FD, Mleziva MB, Callaway JC, Stuart AE (1991) Histamine: a putative afferent neurotransmitter in Limulus eyes. J Comp Neurol 305:527-542.

Burg MG, Sarthy PV, Koliantz G, Pak WL (1993) Genetic and molecular identification of a Drosophila histidine decarboxylase gene required in photoreceptor transmitter synthesis. EMBO J 12:911-919.

Callaway JC, Stuart AE (1989) Biochemical and physiological evidence that histamine is the transmitter of barnacle photoreceptors. Vis Neurosci 3:311-325.

Callaway JC, Stuart AE, Edwards JE (1989) Immunocytochemical evidence for the presence of histamine and GABA in the photoreceptors of the barnacle, Balanus nubilus. Vis Neurosci 3:289-299.

Callaway JC, Lasser-Ross N, Stuart AE, Ross WN (1993) Dynamics of intracellular free calcium concentration in the presynaptic arbors of individual barnacle photoreceptors. J Neurosci 13:1157-1166.
Chudomelka PJ, Murrin LC (1983) Transport of histidine into synaptosomes of the rat central nervous system. J Neurochem 40:830-835.

Elias MS, Evans PD (1983) Histamine in the insect nervous system: distribution, synthesis, and metabolism. J Neurochem 41:562-568.

Eliasof S, Werblin F (1993) Characterization of the glutamate transporter in retinal cones of the tiger salamander. J Neurosci 13:402-411.

Hamberger A, Chiang GH, Sandoval E, Cotman CW (1979) Glutamate as a CNS transmitter II: regulation of synthesis in the releasable pool. Brain Res 168:531-541.

Hardie RC (1987) Is histamine a neurotransmitter in insect photoreceptors? J Comp Physiol [A] 161:203-213.

Hegstrand LR, Simon JR (1985) Histidine transport into rat brain synaptosomes. J Neurochem 45:407-414.

Hudspeth AJ, Stuart AE (1977) Morphology and responses to light of the somata, axons, and terminal regions of individual photoreceptors of the giant barnacle. J Physiol (Lond) 272:1-23.

Hudspeth AJ, Poo MM, Stuart, AE (1977) Passive signal propagation and membrane properties in median photoreceptors of the giant barnacle. J Physiol (Lond) 272:25-43.

Marc RE, Lam DMK (1981) Uptake of aspartic and glutamic acid by photoreceptors in goldfish retina. Proc Natl Acad Sci USA 78:7185-7189.

Martin DL (1992) Synthesis and release of neuroactive substances by glial cells. Glia 5:81-94.

Maxwell GD, Tait J, Hildebrand JG (1978) Regional synthesis of neurotransmitter candidates in the CNS of the moth Manduca sexta. Comp Biochem Physiol 61C:109-119.

Morgan JR, Stuart AE (1996) The sites of $\left[{ }^{3} \mathrm{H}\right]$ histidine uptake within an arthropod eye raise questions about the synthesis of histamine, the photoreceptors' neurotransmitter. Soc Neurosci Abstr 22:367.

Nassel DR, Holmqvist RC, Hardie RC, Hakanson R, Sundler F (1988) Histamine-like immunoreactivity in photoreceptors of the compound eyes and ocelli of the flies Calliphora erthyrocephala and Musca domestica. Cell Tissue Res 253:639-646.

Pirvola U, Tuomisto L, Yamatodani A, Panula P (1988) Distribution of histamine in the cockroach brain and visual system: an immunocytochemical and biochemical study. J Comp Neurol 276:514-526.

Pow DV, Crook DK (1996) Direct immunocytochemical evidence for the transfer of glutamine from glial cells to neurons: use of specific antibodies directed against the D-stereoisomers of glutamate and glutamine. Neuroscience 70:295-302.

Pow DV, Crook DK (1997) Tryptophan is present in glial cells and photoreceptors in the chicken retina. NeuroReport 8:1767-1770.

Pow, DV and Robinson, SR (1994) Glutamate in some retinal neurons is derived solely from glia. Neuroscience 60:355-366.

Sarthy PV (1991) Histamine: a neurotransmitter candidate for Drosophila photoreceptors. J Neurochem 57:1757-1768.

Schnapp BJ, Stuart AE (1983) Synaptic contacts between physiologically identified neurons in the visual system of the barnacle. J Neurosci 3:1100-1115.

Schwartz JH, Elste A, Shapiro E, Gotoh H (1986) Biochemical and morphological correlates of transmitter type in $\mathrm{C} 2$, an identified histaminergic neuron in Aplysia. J Comp Neurol 245:401-421.

Simmons PJ, Hardie RC (1988) Evidence that histamine is a neurotransmitter of photoreceptors in the locust ocellus. J Exp Biol 138:205-219.

Stuart AE, Callaway JC (1991) Histamine: the case for a photoreceptor's neurotransmitter. Neurosci Res [Suppl] 15:S13-S23.

Stuart AE, Morgan JR, Mekeel HE, Kempter E, Callaway JC (1996) Selective, activity-dependent uptake of histamine in to an arthropod photoreceptor. J Neurosci 16:3178-3188.

Tachibana M, Kaneko A (1988) L-glutamate-induced depolarization in solitary photoreceptors: a process that may contribute to the interaction between photoreceptors in situ. Proc Natl Acad Sci USA 85:5315-5319.

Weinreich D, Yu Y-T (1977) The characterization of histidine decarboxylase and its distribution in nerves, ganglia, and in single neuronal cell bodies from the CNS of Aplysia californica. J Neurochem 28: 361-369. 